\title{
Indoor and soil radon measurements in the Hyblean Foreland (South-East Sicily)
}

\author{
Cristina Antoci $\left({ }^{1}\right)$, Giuseppina Immè $\left({ }^{1}\right)$, Santo La Delfa $\left({ }^{2}\right)\left({ }^{3}\right)$, Salvatore Lo Nigro $\left({ }^{1}\right)$, \\ Daniela Morelli $\left({ }^{1}\right)$, Giuseppe Patanè $\left({ }^{2}\right)$ and Giuseppe Alessandro $\left({ }^{4}\right)$ \\ (') Dipartimento di Fisica e Astronomia, Università degli Studi di Catania, Italy \\ ${ }^{2}{ }^{2}$ Dipartimento di Scienze Geologiche, Università degli Studi di Catania, Italy \\ $\left(^{3}\right)$ IRMA-OMEGA, Via Paolo Vasta 158/c, Acireale (CT), Italy \\ $\left({ }^{4}\right)$ Provincia Regionale di Ragusa, Settore Geologia e Geognostica, Ragusa (RG), Italy
}

\begin{abstract}
Indoor radon behavior in two sites of SE Sicily was studied as a function of the soil radon concentration. The chosen locations were Ragusa and Modica towns, placed in the Hyblean Plateau (northern margin of the African Plate). Soil samples were analysed by gamma spectrometry to determine the amount of radionuclides. Indoor air and soil gas radon measurements were simultaneously performed in both sites using active detectors. Radon in soil was measured one meter deep. A positive correlation was obtained between indoor radon concentration and the soil gas concentration.
\end{abstract}

Key words radon - uranium - indoor air - soil gas Hyblean Foreland

\section{Introduction}

Uranium is present in rocks and soil. The most abundant isotope is ${ }^{238} \mathrm{U}$ that decaying generates ${ }^{222} \mathrm{Rn}$.

Radon is a noble gas and thus does not undergo chemical reactions which could preclude its free movement within soil. Once radon is free to move, when it has left its original matrix through the emanation process, it can give rise to different mechanisms of migration, until it arrives at the soil surface and exhales to the atmosphere. The first mechanism of migration is diffusion. The second one is convection, which

Mailing address: Dr. Daniela Morelli, Dipartimento di Fisica e Astronomia, Università degli Studi di Catania, Via S.Sofia 64, 95123 Catania, Italy; e-mail: daniela.morelli@ct.infn.it can occur when a sufficient thermal gradient is available within the soil, depending on many local parameters, such as viscosity, porosity, permeability. The third one is transport by means of gas carrier (Monnin and Seidel, 1997; Etiope and Martinelli, 2002; Yang et al., 2003).

The major sources for indoor radon gases are the soil under the building, the household water and the building material (Swedjmark et al., 1989; Ramachandran et al., 1990; Jonsson, 1991; Kullab, 2005). The principal source of ${ }^{222} \mathrm{Rn}$ inside the home is the soil surrounding the building (Nason and Cohen, 1987; Durrani, 1999), so a correlation between the soil and indoor radon could be expected. In recent years, several national indoor surveys have been performed in different countries (Abu-Jarad and Al-Jarallah, 1986; Diwivedi et al., 1997; Yu et al., 1997; Iakovleva and Karataev, 2001; Canoba et al., 2001; Srivastava et al., 2001; Espinosa and Gammage, 2003; Al-Jarallah et al., 2003) many studies have also been performed on soil gas, particularly in fractured zones (King et al., 1996; Mazur et al., 1999; Jonsson et al., 1999; Choubey et al., 1999; Durani, 
1999; Al-Tamimi and Abumarad, 2001; Vaupotiã, 2003).

Since uranium and radium present in the soil are the main source of indoor radon, in this study, measurements of radionuclides in soil along with radon concentration measurements in the soil gas air and indoors were carried out in SE Sicily. The relation between soil gas radon concentration and indoor air radon concentration is also shown and commented.

\section{Measurements}

A study was carried out in the winter of $2003 / 2004$. It was performed in two different sites: Ragusa and Modica (a village $8 \mathrm{~km}$ southeast of Ragusa). Simultaneous indoor air and soil gas radon measurements were performed. In order to determine the amount of radionuclides, gamma spectrometry was carried out on soil samples collected in the two sites.

\subsection{Geology of the area}

The two investigation sites are located in the Central Hyblean Plateau (south-east Sicily) (fig. 1). The Hyblean Plateau is part of the northern margin of the African Plate and has remained a relatively undeformed foreland during the Neogene collisional process affecting the African-European convergent belt; it consists of $c a .6000 \mathrm{~m}$ of carbonates and marls with intercalations of volcanic horizons, which have occurred at several episodes (Patacca et al., 1979; Bianchi et al.,

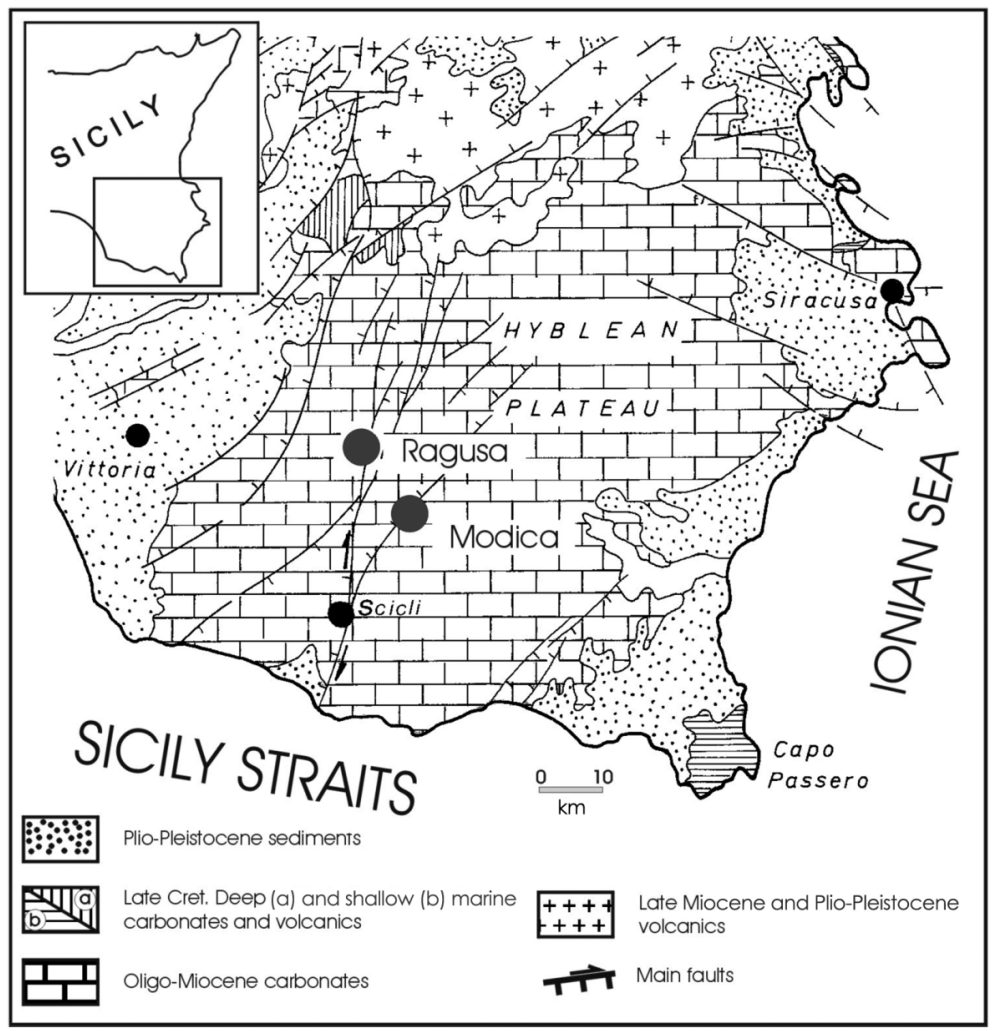

Fig. 1. Site location: the Hyblean Foreland. 
1989; Ragg et al., 1999). The rock successions in which Ragusa and Modica lies are OligoMiocene carbonates.

\subsection{Indoor radon study}

Indoor radon measurements were made in rooms characterized by similar building materials in the basement. The rooms were closed before the measurements beginning for a period of one week and sealed throughout the investigation period, to avoid external influences on the measurements. The edifices were made of cement, sand, bricks and concrete, having one window and one door. The chosen rooms were placed in the basement. Continuous measurements were carried out with an ALPHAGUARD (Genitron Instruments) device operating in diffusion mode (the radon enters into the ionization chamber by natural diffusion through a filter that allows only radon to enter). In Modica the measurements were performed from 1 st December 2003 till 11th December 2003, while in Ragusa from 17th January 2004 till 5th February 2004.

\subsection{Soil radon study}

Soil measurements were curried out over the monitored rooms. Measurements were performed with an ALPHAGUARD (Genitron Instruments) device with the soil probe one meter deep, connected by means of a pump with flow rate of $0.051 \mathrm{~min}^{-1}$ to the detection system operating with an ionisation chamber. Before reaching the detector, the soil radon passes through an aqua stop filter to eliminate the moisture, and then to a progeny filter to allow the only ${ }^{222} \mathrm{Rn}$ to pass. In both sites continuous soil gas measurements were performed simultaneously with the indoor ones.

\subsection{Uranium concentration in soil sample}

Gamma-ray spectrometry was used to determine the radionuclides activity concentration in sample of soil of the investigated area. A high- purity germanium E\&G Ortec (HpGe), with an efficiency of $30 \%$ was employed.

The samples were dried at about $80^{\circ} \mathrm{C}$ for 4 $\mathrm{h}$ to eliminate the humidity, then crushed and homogenized until obtaining a $250 \mu \mathrm{m}$ powder and dried at about $80^{\circ} \mathrm{C}$ for $24 \mathrm{~h}$ to eliminate the residual humidity. Then the samples were weighed and placed in a Marinelli beaker of 100 $\mathrm{cm}^{3}$. This kind of beaker allows only a $5 \mathrm{~mm}$ thick sample and therefore the gamma self-absorption negligible. Each sample was sealed for 4 weeks to reach the secular equilibrium (ASTM, 1983, 1986). The acquisition time was 18000 s. For determination of the full-energy peak efficiency in the energy range from 60 to $2000 \mathrm{keV}$ a calibration source, with the same geometry as the samples, was prepared by means of a mesh of known activity.

\section{Experimental results and discussion}

Continuous measurements in soil and indoors, with an integration rate of $10 \mathrm{~min}$, were simultaneously performed. Measurements in Modica were carried out from 1st December 2003 to 11th December 2003, while in Ragusa from 17th January 2004 to 5th February 2005. Figure $2 \mathrm{a}, \mathrm{b}$ reports the concentration of radon in indoor air and soil gas radon for the two investigated sites. To better underline the general trend the daily mean was calculated and reported in fig. 3a,b. From this figure it can be seen that the obtained trends for the Modica site show a clear correlation between soil and indoor radon concentration. The same result is less evident for the trends obtained for Ragusa. Calculating the linear coefficient $R$, between in-soil and indoor radon, $R=0.84$ was found for the Modica site and $R=0.09$ for the Ragusa. To better investigate the behaviour of the two sites, a cross-correlation of the two signals (soil and indoor radon) was performed. Figures 4 and 5 report the results for Ragusa and Modica, respectively.

The soil and indoor daily mean radon concentration trends were normalized to the arithmetic mean value, calculated throughout the investigated period, to make the two series better comparable. 

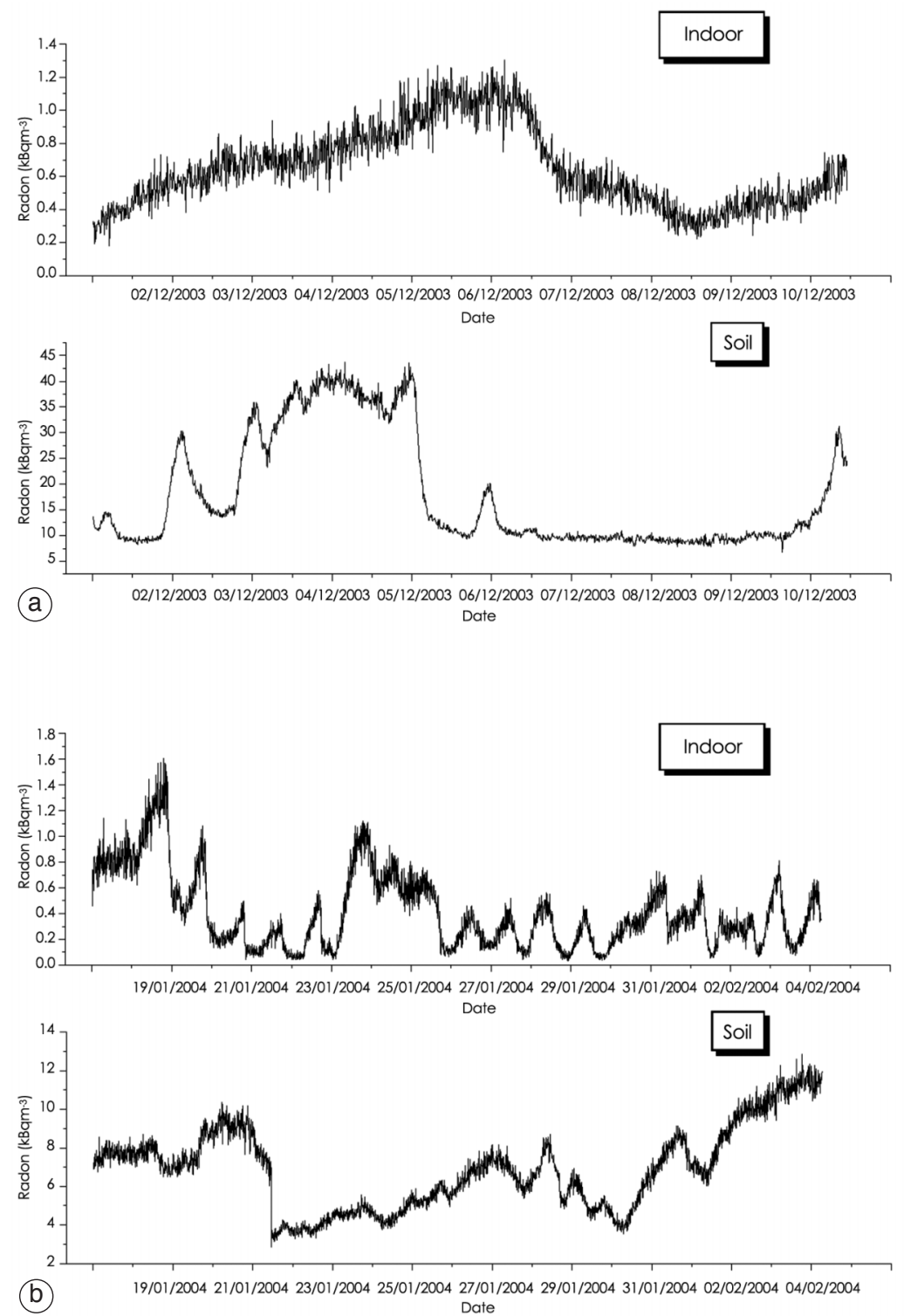

Fig. 2a,b. Radon concentration: a) Modica December 1st, 2003-December 11th, 2003; b) Ragusa January 17th, 2004-February 5th, 2004.

A cross correlation analysis was carried out. It is a standard method of estimating the degree to which two series are correlated. Considering the two series the cross correlation $r$ at delay $d$ is defined as the following function:

$$
r(d)=\frac{\sum_{i}[(x(i)-\bar{x}) *(y(i-d)-\bar{y}]}{\sqrt{\sum_{i}(x(i)-\bar{x})^{2}} \sqrt{\sum_{i}(y(i-d)-\bar{y})^{2}}}
$$


where the two series are indicated with $x(i)$ and $y(i)$ respectively; $\bar{x}$ and $\bar{y}$ are the arithmetic means of the corresponding series; $d=1,2, \ldots, N-1$ is the delay (days, being the two series daily trend).

From figs. 4 and 5 it can seen that the maximum correlation at both sites is for $d=0$, indicating that indoor and soil radon concentration have the maximum correlation without delay,

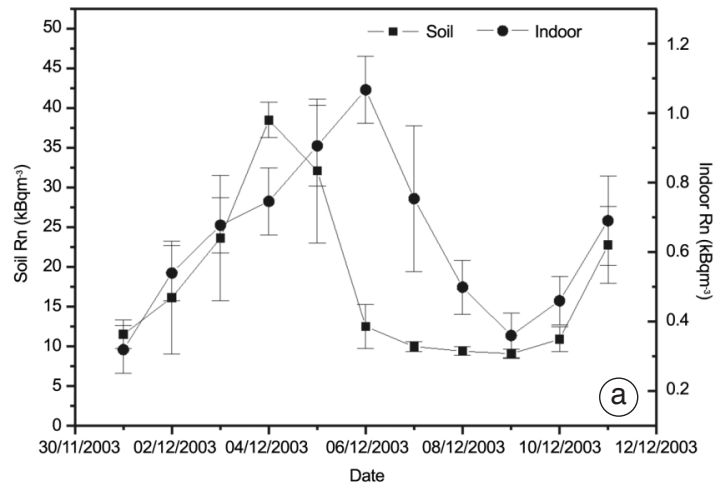

even if the correlation is higher in Modica than in Ragusa.

Looking at the recorded indoor and soil radon values, the two sites show different characteristics. Table I lists the average over the investigation period. It can be observed that: i) the mean soil radon concentration is $7 \mathrm{kBq} \mathrm{m}^{-3}$ in Ragusa and $18 \mathrm{kBq} \mathrm{m}^{-3}$ in Modica, while the

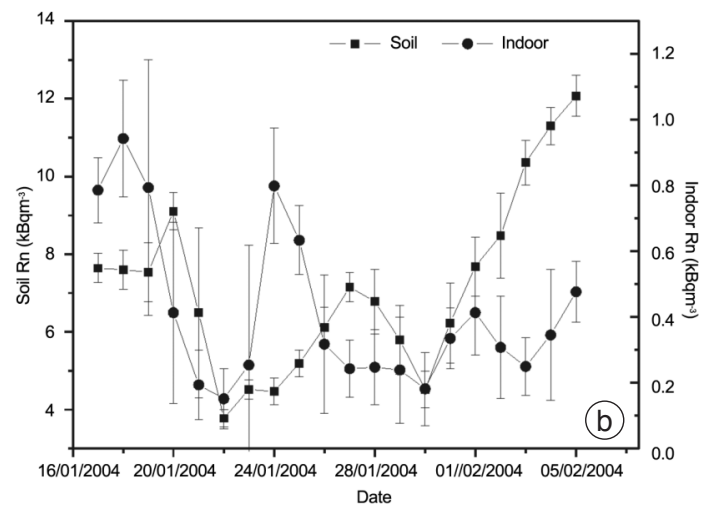

Fig. 3a,b. Radon daily mean concentration: a) Modica; b) Ragusa.
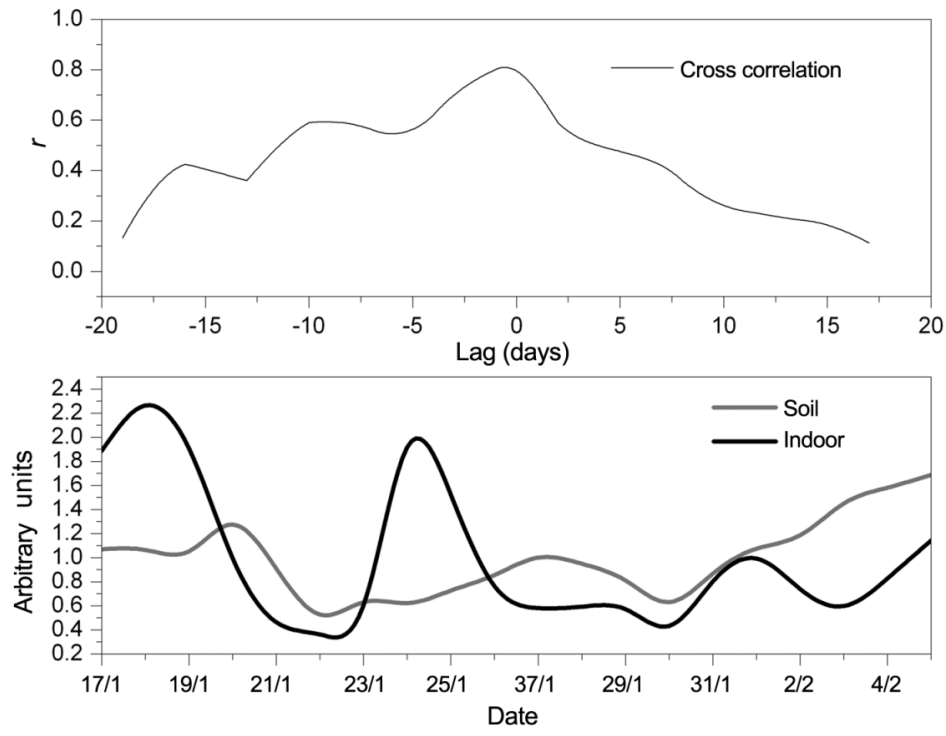

Fig. 4. Cross-correlation (upper plot) between soil and indoor radon trend (down plot) site of Ragusa. 

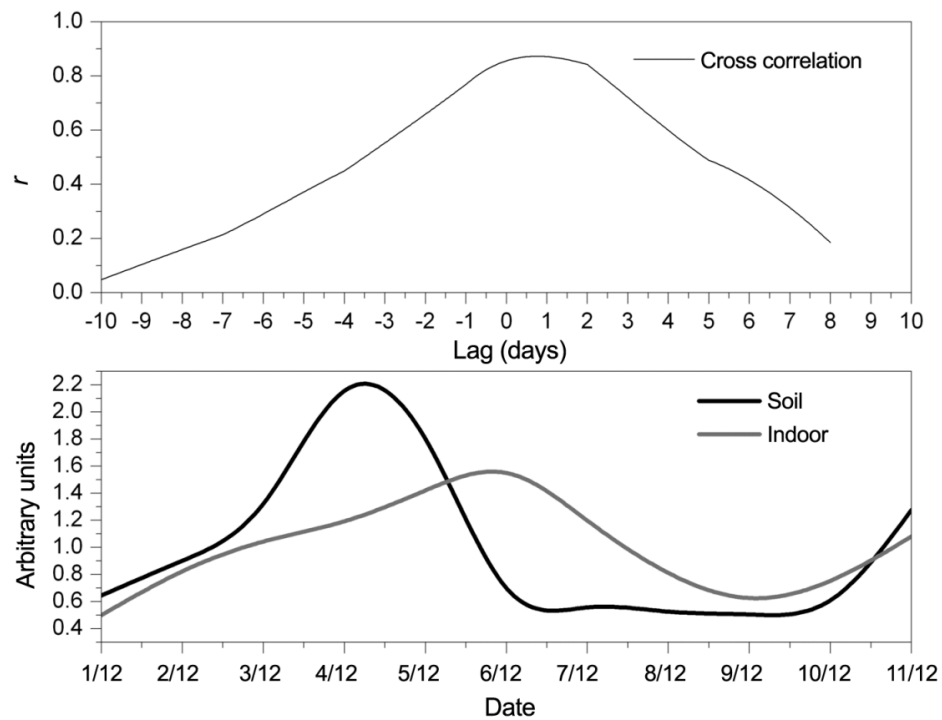

Fig. 5. Cross-correlation (upper plot) between soil and indoor radon trend (down plot) site of Modica.

Table I. Indoor and soil radon concentration means all over the investigation period.

\begin{tabular}{|c|c|c|c|c|}
\hline \multirow[t]{2}{*}{ Site } & \multicolumn{2}{|c|}{$\begin{array}{c}\text { Soil } \\
\operatorname{Rn}\left[\mathrm{Bq} \mathrm{m}^{-3}\right]\end{array}$} & \multicolumn{2}{|c|}{$\begin{array}{c}\text { Indoor } \\
\operatorname{Rn}\left[\mathrm{Bq} \mathrm{m}^{-3}\right]\end{array}$} \\
\hline & Mean & Stand. dev. & Mean & Stand. dev. \\
\hline Modica & 18000 & 11000 & 700 & 250 \\
\hline Ragusa & 7000 & 2000 & 400 & 290 \\
\hline
\end{tabular}

mean indoor radon is $400 \mathrm{~Bq} \mathrm{~m}^{-3}$ in Ragusa and $700 \mathrm{~Bq} \mathrm{~m}^{-3}$ in Modica; ii) soil radon values show fewer fluctuations in Ragusa than in Modica, the relative percentage errors are, in fact, of $28 \%$ and $61 \%$ respectively; iii) indoor values are have fewer fluctuations in Modica than in Ragusa, the relative percentage errors, in this case, are $35 \%$ and $72 \%$ respectively. These differences may be linked to the difference in tectonic disturbance and porosity of the soil, the building materials having been chosen with the same characteristics. Looking at the mean values it is also possible to observe that the percentage of indoor radon concentration with re- spect to the soil is $6 \%$ for Ragusa and $4 \%$ for Modica. This first results indicate that the exhalation rate in Ragusa soil is higher than that in Modica, indoor accumulation is favoured in Ragusa. This could indicate that the Ragusa area is more fractured than the Modica one as the exhalation rate is strictly linked to the degree of soil fracturation.

The results obtained by gamma spectrometry (table II) also indicate different values on radionuclides concentration in the two sites, otherwise the ratio between the amount of the elements post ${ }^{222} \mathrm{Rn}\left({ }^{214} \mathrm{~Pb}\right.$ and $\left.{ }^{214} \mathrm{Bi}\right)$ and that of ${ }^{226} \mathrm{Ra}$ is higher in Ragusa than in Modica. The larger disequilibrium between ${ }^{214} \mathrm{~Pb},{ }^{214} \mathrm{Bi}$ and ${ }^{226} \mathrm{Ra}$ recorded in Modica justifies the higher in-soil values. High disequilibrium, in fact, is due to radon escape that is linked to the soil porosity, favouring the emanation process. Under this hypothesis, we can justify the results obtained: i) the rocks in the Modica area are more porous, favouring radon emanation (high in soil radon concentration) and the area being less fractured the in soil accumulation is higher with respect to indoor one; ii) the rocks in the Ragusa area are less porous so the radon 
Table II. Radionuclides amount in the soil samples.

\begin{tabular}{|c|c|c|c|c|c|c|}
\hline Sample code & $\begin{array}{c}\text { Radioactive } \\
\text { series }\end{array}$ & $\begin{array}{l}\text { Element } \\
\left(\mathrm{Bq} \mathrm{kg}^{-1}\right)\end{array}$ & Concentration & $\begin{array}{l}\text { Standard } \\
\text { deviation }\end{array}$ & $\begin{array}{l}\text { Weighted } \\
\text { mean }\end{array}$ & $\begin{array}{l}\text { Standard } \\
\text { deviation }\end{array}$ \\
\hline \multirow[t]{3}{*}{ Modica } & pre-radon & $\begin{array}{l}\text { Th-234 } \\
\text { Ra-226 }\end{array}$ & $\begin{array}{l}18.37 \\
54.11\end{array}$ & $\begin{array}{c}6.35 \\
11.16\end{array}$ & & \\
\hline & ${ }_{\text {post-radon }}{ }^{238} \mathrm{U}$ & $\begin{array}{l}\mathrm{Pb}-214 \\
\mathrm{~Pb}-214 \\
\mathrm{Bi}-214\end{array}$ & $\begin{array}{c}19.97 \\
4.32 \\
13.91\end{array}$ & $\begin{array}{l}1.99 \\
1.20 \\
2.68\end{array}$ & 10.99 & 0.84 \\
\hline & ${ }^{232} \mathrm{Th}$ & $\begin{array}{l}\mathrm{Pb}-212 \\
\mathrm{Ac}-228\end{array}$ & $\begin{array}{l}9.46 \\
1.11\end{array}$ & $\begin{array}{l}0.58 \\
1.78\end{array}$ & 8.11 & 0.34 \\
\hline \multirow[t]{3}{*}{ Ragusa } & pre-radon & $\begin{array}{l}\text { Th-234 } \\
\text { Ra-226 }\end{array}$ & $\begin{array}{c}16.03 \\
140.56\end{array}$ & $\begin{array}{l}11.20 \\
9.45\end{array}$ & & \\
\hline & ${ }_{\text {post-radon }}{ }^{238} \mathrm{U}$ & $\begin{array}{l}\mathrm{Pb}-214 \\
\mathrm{~Pb}-214 \\
\mathrm{Bi}-214\end{array}$ & $\begin{array}{l}43.27 \\
43.66 \\
41.54\end{array}$ & $\begin{array}{l}1.78 \\
1.62 \\
2.29\end{array}$ & 43.06 & 1.06 \\
\hline & ${ }^{232} \mathrm{Th}$ & $\begin{array}{c}\mathrm{Pb}-212 \\
\mathrm{Ac}-228 \\
\mathrm{~T} 1-208\end{array}$ & $\begin{array}{l}3.10 \\
3.11 \\
1.05\end{array}$ & $\begin{array}{l}0.31 \\
1.29 \\
0.57\end{array}$ & 2.65 & 0.27 \\
\hline
\end{tabular}

emanation is not favoured (low in soil radon concentration) and as the area is more fractured the indoor accumulation is higher than the soil one.

\section{Conclusions}

Radon measurements were performed indoors and in the soil in Ragusa and Modica (SE Sicily). Different geological features characterize the two sites while the dwellings, where the indoor measurements were done had the same building typology and materials. The results of simultaneous indoor and soil radon measurements in both sites showed a positive correlation. From the gamma-ray analysis it was also possible to explain the obtained differences in values. In particular from the ${ }^{214} \mathrm{~Pb} /{ }^{226} \mathrm{Ra}$ and ${ }^{214} \mathrm{Bi} /{ }^{226} \mathrm{Ra}$ ratios it is clear that the Modica soil is more porous than the Ragusa one. Moreover the continuous soil and indoor radon measurements have evidenced that the Modica area, as expected, is more fractured. The results obtained indicate that in the Modica area the predominant process involved is radon emanation, while in the Ragusa area it is exhalation.

\section{Acknowledgements}

We thank the Provincia Regionale di Ragusa, Assessorato Territorio e Ambiente, Settore Geologia e Geognostica, directed by Dr. S. Buonmestieri, for having contributed to this work providing the instruments and the locations for the investigation.

\section{REFERENCES}

ABu-JARAD, F. and M.I. Al-JARALlaH (1986): Radon activity in Saudi houses, Radiat. Prot. Dosim., 14, 243-249.

Al-Jarallah, M.I., X. FaZAl-UR-Rehman and F. ABUJARAD (2003): Indoor radon survey in dwellings of some regions in Yemen, Radiat. Meas., 36, 449-451.

AL-TAMIMI, M.H. and K.M. ABUMURAD (2001): Radon anomalies along faults in north of Jordan, Radiat. Meas., 34, 397-400.

ASTM (American Society for Testingand Materials) (1983): Standard method for sampling surface soil for radionuclides C 998-83, Annual Book of ASTM Standards (Philadelphia, PA), 512-514.

ASTM (American Society for Testingand Materials) (1986): Recommended practice for investigation and sampling soil and rock for engineering purposes D 420, Annual Book of ASTM Standards (Philadelphia, PA), 109-113.

Bianchi, F., S. Carbone, M. Grasso, G. Invernizzi, F. Lentini, G. Longaretti, S. Merlini and F. Moscardi- 
NI (1989): Sicilia Orientale: profilo geologico NebrodiIblei, Mem. Soc. Geol. It., 38, 429-458.

Canoba, A., F.O. Lopez, M.I. Arnaud, A.A. Oliveria, R.S. Neman, J.C. Hadler, P.J. Iunes, S.R. Paulo, A.M. Osorio, R. Aparecido, C. Rodriguez, V. Moreno, R. Vasquez, G. Espinosa, J.I. Golzarri, T. Martinez, M. Navarrete, I. Cabrera, N. Segovia, P. Pena, E. Tamez, P. Pereyra, M.E. Lopez-Herrera and L. Sajo-Bohus (2001): Indoor radon measurements and methodologies in Latin American countries, Radiat. Meas., 34, 483486.

Choubey, V.M., K.S. Bist, N.K. SAINI and R.C. Ramola (1999): Relation between soil-gas radon variation and different lithotectonic units, Garhwal Himalya, India, 51, 487-592.

DuRANI, S.A.(1999): Radon concentration values in the field: correlation with underlying geology, Radiat. Meas., 31, 271-276.

Dwivedi, K.K., S. Ghosh, S. Singh, Limatimjen, J. Satyanarayana, G.S. Murthy, J. Prasad and A. Srivastava (1997): Indoor radon measurements in some Indian cities, Radiat. Meas., 28, 647-649.

EsPinOSA, G. and R.B. GAMmAGE (2003): A representative survey of indoor radon in sixteen regions in Mexico City, Radiat. Prot. Dosim., 103, 73-76.

Etiope, G. and G. MARTinelli (2002): Migration of carrier and trace gases in the geosphere: an overview, Phys. Earth Planet. Inter., 129, 185-204.

IAKOVLEVA, V.S. and V. D. KARATAEV (2001): Radon level in Tomsk dwellings and correlation with factors of impact, Radiat. Meas., 34, 501-504.

JonsSON, G. (1991): Solid state nuclear track detectors in radon measurements indoor and in the soil, Int. Radiat. Appl. Instr. D, 19 (1-4), 335-338, doi: 10.1016/13590189(91)902008-y.

Jonsson, G., C. Baixeras, R. Devantier, W. Enge, L.L. Font, K. Freyer, R. Ghose and H-C. Treutler (1999): Soil radon levels measured with SSNTD's and the soil radium content, Radiat. Meas., 31, 291-294.

KING, C.-H., B.-S. KING and W.C. Evans (1996): Spatial radon anomalies on active faults in California, Appl.
Geochem., 11, 497-510.

Kullab, M. (2005): Assessment of radon-222 concentrations in buildings, building materials, water and soil in Jordan, Appl. Radiat. Isot., 62, 765-773.

Mazur, D., M. JaniK, J. Loskiewicz, P. Olko and J. Swakon (1999): Measurements of radon concentration in soil gas by CR-39 detectors, Radiat. Meas., 31, 295-300.

Monnin, M.M. and J. SEIDEL (1997): Radon and volcanic surveillance, in Radon Measurements by Etched Track Detectors: Application in Radiation Protection, edited by S.A. DurRani and R. ILIC (Earth Science and the Environment, World Scientific), 301-318.

NASON, R. and B.L. COHEN (1980): Correlation between ${ }^{226} \mathrm{Ra}$ in soil, ${ }^{222} \mathrm{Rn}$ in soil gas, and ${ }^{222} \mathrm{Rn}$ inside adjacent houses, Health Phys., 52, 73-74.

Patacca, E., P. Scandone, G. Giunta and V. Liguori (1979): Mesozoic paleotectonic evolution of the Ragusa zone (southeastern Sicily), Geol. Rom., 18, 331-369.

RagG, R., M. Grasso and B. Muller (1999): Patterns of tectonic stress in Sicily from borehole and breakout observations and finite element modelling, Tectonics, 18, 669-685.

RAMACHANDRAN, T.V., M.C. SubBa RAMMU and U.C. Mishra (1990): A correlation study of radon in dwellings with radium content of soil, Current. Sci., 59, 979-982.

Srivastava, A., M.R. Zaman, K.K. Dwivedi and T.V. RaMACHANDRAN (2001): Indoor radon level in the dwellings of Rajshahi and Chuadanga regions of Bangladesh, Radiat. Meas., 34, 497-500.

Swedjemark, G.A., H. Wahren, A. Makilato and W. Tell (1989): Experience from indoor radon-daughther schemes in Sweden, Environ. Int., 15, 253-260.

VAupotiñ, J. (2003): Indoor radon in Slovenia, Nuclear Tecnol. Rad. Prot., 2, 36-43.

YANG, T.F., C.Y. Chou, C-H. Chen, L.L. ChYI and J.H. JIANG (2003): Exhalation of radon and its carrier gases in SW Taiwan, Radiat. Meas., 36, 425-429.

Yu, K.N., E.C.M. Young, M.J. Stokes, Z.J. Guan and K.W. CHO (1997): A survey of radon and thoron progeny for dwellings in Hong Kong, Health Phys., 73 (2), 373-377. 